\title{
ROLE OF THE GOVERNMENT IN THE IMPLEMENTATION OF LOCAL DEVELOPMENT CASE STUDY ON NATIONAL PROGRAMA LOCAL DEVELOPMENT
}

\author{
*Francisco Guterres
}

\author{
Graduate student Master of Public Administration, Universidade da Paz, Dili -Timor-Leste
}

\section{ARTICLE INFO}

\section{Article History:}

Received $17^{\text {th }}$ February, 2021

Received in revised form

$06^{\text {th }}$ March, 2021

Accepted $14^{\text {th }}$ April, 2021

Published online $30^{\text {th }}$ May, 2021

\section{Key Words:}

Government, Implementation,

Development.

\section{*Corresponding author:}

Fábia Máximo Bezerra Borges

\begin{abstract}
This thesis is entitled “ The Role of Government in the Implementation of Local Development (Case Study in the Administrative Post of Uatolari) "Local development is a measure of national development where the development growth in an advanced sub-district will automatically reflect the development itself. In the sub-district, development has been carried out which in the research will highlight physical development. Physical development in the sub-district in accordance with its implementation has not reached the planned target in accordance with the expectations of the community in the Uatolari sub-district. Thus, the problem can be formulated as follows: How is the government role in implementing local development?. The theoretical basis used in this chapter, the writer wants to explain the theory according to Prajudi (2000), the role of government in the implementation of development, while the method used in this research is descriptive method with research techniques such as qualitative data analysis, the subject of what is being studied is The functions and tasks that exist in the Uatolari sub-district and the object under study are affirming the implementation of physical development in the Uatolari sub-district consisting of 6 people, the instruments used are observation, interviews, documentation and interviews (asking and answering) to collect data and to process data to completion. The conclusion from the research results found that the role of the government in implementation in the uatolari sub-district is still lacking due to a lack of control, therefore it is necessary for the central government to monitor, supervise the physical development that is being built or in progress so that it will accelerate according to the specified time. Recommended to the Ministry of Home Affairs and Regional Development to pay attention to the Viqueque district national development agency in order to accelerate the process of implementing local development, in accordance with the expectations of the community, especially the ongoing infrastructure development in accordance with the national development strategic plan.
\end{abstract}

Copyright (C) 2021, Francisco Guterres. This is an open access article distributed under the Creative Commons Attribution License, which permits unrestricted use, distribution, and reproduction in any medium, provided the original work is properly cited.

Citation: Francisco Guterres, 2021. "roe of the government in the implementation of local development case study on national programa local development ", International Journal of Development Research, 11, (05), 47220-47231.

\section{INTRODUCTION}

The Development Goals are not just the primary physical landscape, clothing, food and housing, health and other sectors but are designed to hatred and grow as a whole in the development of the body and the happiness of the classroom. Thus, in the same way, the orderly development of the Nation of the Democratic Republic of TimorLeste is carried out in a physical and non-commercial manner. With fiscal means such as Road Development, water production, construction, construction such as Construction of School Building, Village Building, and Construction of houses for poor people as well as non- physical development such as leadership training, public administration, a training course held in each Village. The community includes the village community of Vessoru, Babulu, Afaloika, Waitame, Makadiki and Matahoi, as the objective of the Democratic Republic of Timor-Leste (RDTL), expressed in the Constitution of the Democratic Republic of Timor-Leste, article 6 on the basic objectives of the country as stated in the RDTL Constitution: Builds in a society based on social justice, raising citizens' wellbeing for the body and the. Article 6 (e) of the Constitution of the Democratic Republic of Timor-Leste (LRC), as stated above, the community development can be strengthened by the development of human resources, including the creation of five means that reinforce, create consensus and work with the community to make productive, as well as produce, resulting in a trade field. Thus, Village communities can improve their efforts and take advantage of any funding and capacity of the force and income generation in the way they live. Thus, it is possible to achieve a goal of welfare in the community. Thus, it is necessary to create ideas and work together with communities and Villages, as well as create new employment opportunities for community members to gain income and improve livelihoods. To achieve good community life targets, the development also sets specific objectives according to the program of Development planned 
by the Village and community. The municipality administrative post of Uatu-Lari in Viqueque has not yet been relocated to the community's will, data on the community's will: the Alkatra road from the administrative post of Baguia to the Village (Uatolari Administrative Post for Afaloi, Babulu and Vessoru), construction of water tanks and tanks, Community Health Post, irrigation and Power in the Villages. Since the community in Uatolari Administrative Post still doesn't have access to drinking water, the community has never had access to electricity, the community still doesn't have access to electricity, the vast majority of the paddy fields remain abandoned because irrigation is damaged due to the impacts of the rain (Natural Disasters), the community has difficulty accessing transport, the Health Centre which has not yet been completed with stakeholders, entrepreneurs and staff, many schools have been damaged. Through the aforementioned points, it is stated that the implementation of development is not according to the target, which has an impact on the community in the Uatolari administrative post does not have access to roads, making it difficult for the community to carry out economic life, water and also impacts on the community to draw water from the river, because the condition of this post is not in poor condition when the rainy season, it does not have enough conditions for the community to access to electricity, the community did not have an impact on the electricity supply power to fire that has on the community's health risks.

Development issues were not satisfied with the targets defined by the Government, due to the lack of the role of the government in the development of villages and thus the problem of drafting this research is that the results of the research can be addressed by village authorities and thus become information to the government. The reality of Village Development is physical, when it is linked to the role of encouraging community service delivery is low and it conducts less aid activities. Acording with Koontz O. Development means that: a process that is always carried out with plans to improve the lives of society in economic, political and cultural aspects) the model of social change is continuing from one phase to another, organised by the National target and compared to traditional projects. The aim of this understanding was that development as a export system is to create change through actions that are focussed on the success of development itself. Other mechanisms to implement programs in order to increase Village development and to strengthen institutional capacity such as: training of Village structures,technical staff in the Villages does not yet have in-depth knowledge about how to conduct programs and financial reporting, even though TimorLeste is also in the National Village Development Program (PNDS) environment which is carried out with capacity development capacity, especially the role of the government in improving development planning and reducing poverty. Constitution of the Democratic Republic of Timor-Leste (CRDTL), Dili, 2002, article 6 (e ), page 13 Obstacles faced in relation to natural resources and the sensible performance of the professional management and protection. The National Program for Village Development (PNDS) is a process that may focus on community disability, which has been the most demanding formal process and capacity to motivate the community in the area of development. Taking into account the role of the community in development activities, through institutional institutions, the organization in the villages plays a role in preventing the social trend that occur in the Village. Governance in the role of social problem delivery in the Village is that there are arrangements for all development activities through planning (program determination) and control (see program) and maintenance (see back). However, at the same stage the above can be seen.

The role of the government in the implementation of development area is still low in the area of basic infrastructure such as irrigation, rural development, water supply, electricity, Community Health Post, School and Communication between the Local Government and the Community, lack of control; minimal delays due to working means between community leaders and the national government, which is very difficult to achieve development in the Villages. The goal is not the same as the plan, from another elbow, which can be seen as a disability that is a challenge and community participation. According to the observations of the owner, less than the results of the development agreement in the village and have not yet reached optimal results. Given the lack of capacity of the government to pay attention, effort and capacity to the community, the means of participation in development arrangements, good planning, control and evaluation of development programs are sometimes carried out and implemented. Village development is not well developed according to needs due to geogeneric factors, motivations, control, planning, key government roles, and community participation. In a phrase the idea that comes from the knowledge of Bintoro Tjokrousbao (1998) "Development is a dynamic process of the involvement of all planned and guiding activities that have the participation of society as a fundamental force to achieve economic changes that enhance the quality of life of society as per human value." This means that development is a very dynamic process because of the involvement of civil society as the basis for economic change in society. In relation to the definition or argument above, the owner has the will to choose the topic of Master of Public Administration: "The role of the Government in the implementation of Local Development (Case Study on the PNDS in Uatolari Administrative Post)".

Fromulation Problem: Based on the identification of the above problem, write the owner of the formulate the problem: How does the Government play in implementing Local Development?

Objetive of Research: The purpose of the research was to analyse and prove in accordance with Schwandt, (2007), that the qualitative research objectives (qualitative purpose statement) informed about the central phenomenon investigated in qualitative research show the research carried out in a manner that was comprehensive on the role of the Government in the implementation of local development.

Problem Limitation: The owner reports that the problem of the writer's writing is to talk about the role of the Government in the Implation of Local Development in Uatolari Administrative Post.

\section{LITERATURE REVIEW}

Fundamnethal Theory: In this chapter, the owner explains or clearly the "Role of the Government in the Implementation of Local Development" To deepen the writing of participants with legal theory under Kuncoro said: "The spirit of dependency is based on the spirit of thinking, which is demonstrated through the system of influence in the classroom in society that refers to this theory. But dependence occurs in the international context between the countries and poor (as follows);

The Role of Government : The role of the Government is to follow up on the performance of the sub-district government aligned by community through a generation of elections. The role of government in development is as follows: Prajudi (2000) The government's duties are: "Among other things, state administration, State households, governance, development and environmental preservation. Meanwhile, the government functions are regulating, fostering the police and judiciary community. "

The Government schedule is: "Among state administration, family or government, development and environmental prevention. It is considered the function of the government to govern, promote community and judicial police.

The Government is an individual group of legal authority that protects the conduct of decisions and decisions made by the government in accordance with the law and regulations that promote the entire life of the community. In relation to this suggestion, only a brief conclusion is that To achieve government tasks in the implementation of decisions according to their functions, how to regulate the development process and environmental prevention in the community is the government's legal authority to protect the implementation of decisions according to the life of the community. According to Kancil (1987) Government is: "A mixed meaning for 
various jobs; implementation of public enterprises, businessmen of government assets, implementation of public works, supervision in various forms at the wishes of the people, regulating the legal position of the people in fact in granting corporate licenses, tax collection assistance, orders and so on.”. (Governance:“ Understanding between different work undertaken; implementation of public companies, public goods, implementation of public works according to the community's wishes is based on the tax reality, which is covered by requests for registration"). Executing activities in accordance with the rules of legal system in the border of the state, whether personal or citizen, individuals or persons, are typically within the government component of society to society. In the light of the government's vision of law and responsibility on governmental issues or issues of respect for the interests of the state in society. Village government according to Ndraha (1992) in his book dimensions of government says that: "Government is the lowest government organization based on decentralization that is placed under and directly responsible to the government of the sub-district concerned. The Government is an individual group of legal authority that protects the conduct of decisions and decisions made by the government in accordance with the law and regulations that promote the full life of the community.

In the same way, the idea of Kancil (1987) of Government is: "A mixed meaning for various jobs; the implementation of public enterprises, businessmen of government assets, the implementation of public works, supervision in various forms at the wishes of the people, regulating the legal position of the people in reality in granting corporate licenses, tax collection assistance, orders and so on."

"An understanding of the work undertaken in a variety of ways; the implementation of public companies, public goods, the implementation of public works according to the community's wishes is based on the tax reality covered by requests for transparency"

The historical discretion base that explains about the government in a Village that is smaller than the country is approaching the real situation in a Village that has an issue. Menurut Eduward (1992) states that the term government has four meanings, namely: "First, it shows the activity or process of governing, namely exercising control over other parties. Second, it shows that State problems in the above activities or processes were encountered. The third shows the people who are burdened with the duty to ask. The fourth shows the means of the method or system, by which a particular society is in government"

The term government has at least 4 significance: 1 . Sample of activity or governance processes undertaken or exercising control over the other party; 2. Sample of problems in the activities faced by the State; 3. The sample of those who have a question; 4. Sample the methods or personal governance system; In the opinion of the above, the owner has written his or her conclusions that an important role of a leader in improving the system of sharing power in the community or local government in the implementation of national development, which is the least governance of a sub-district within a country that is specifically serving the Village staff.

The Government is an individual group of legal authority that protects the conduct of decisions and decisions made by the government in accordance with the law and regulations that promote the entire life of the community. Based on the theory mentioned above, the central or regional government is completely governed by a high role to play, and regulated by these guidelines with powers to be implemented in accordance with the method of legality of authority.

In addition, the Leimare (1987) said that: "Government affairs are in special hands under the ministries, so it is not about government functions in the sense of state structure, controlled what is called governmental service has a special task, namely to ensure that these special services in their territory remain in touch. each other and also remain focused (attention) on local interests with all their distinctive characteristics. This effort is necessary because the special service originates from and is therefore led by the central ministries, therefore there is a danger that in the same area each service will move away from other services and hence from local needs.

"The issue of governance is specific in the ministry, attending or dealing with the role of the government with a sense of state, with chair ship of governance services without special tasks, but with special emphasis on common interests with special characteristics. There is a need for sporadic based on special services, directed by the competent ministries in the Central and regional or agency, in accordance with local needs. According to the theory mentioned above, the central government does not have the power to regulate or complete control the implementation of development activities carried out in the country's productive and efficient sectors. Relevant with the central government need to transform the responsibility of the central government to regional government for the implementation of a serious development program with responsibility between the central government and the regional government. According to Frederiec (1987) about policy which says that: "Policy is an action that leads to the goals proposed by a group or government in a certain environment in connection with certain obstacles while looking for opportunities to achieve goals or realize the goals set forth in a certain environment Want" In terms of policy making decisions, "policymaking is a measure that has the objective of a group or government in a specific environment full of challenges and others seek opportunities to achieve a desired goal". Based on the theory explained above, the education policy sector is an important sector in the difficult life of the state in relation to human resources based on quality based on the education system relevant to timely progress in meeting existing employment challenges. Sojito (1990) defines: "Local government is" a legal community unit that has certain territorial boundaries that has the right, authority and obligation to regulate and manage its own household. The local government is a community legal unit that has the right to authorization and obligation to regulate the direct use of family property." "The local government is a community legal unit that has been the right to authorization and obligation to regulate the direct use of family property. " Mean while Hdiyono and Donny (1984) stated that: "Local government is the State's apparatus to carry out the interests of the people in the region "Local government is a state equipment that always holds community interests in the regional".

From these two views, the central government and regional government see that these two views are strongly inspired in the regional government system to preserve regional appropriate regional interests in order to provide regional financial support.

The role of the Village Chief regulated by Decree Law number: 5 / 2004, section 3 and 2 are:

a. Kompetensia xefi Village, la hare'e ba posibilidade ne'ebé kompormi lei reprezenta ofisial Village iha reuniaun prisipal sira hodi kontuinua fo solusaun ne'ebé kompremente obrigasaun husi parte nebe deit mak iha.

b. Kompete parte Village sira :

c. The competencies of the Village Chief are not given to the possibility that the law acts as a means for representing Village officials in the prison meetings to include a comprehensive solution to the obligations of any party.

d. It is incumbent upon the Village authorities:

1. Coordination in the implementation of decision-making, deciding the results by village councils with elements as well as consulting in communities.

2. seeking a detailed solution in the village to provide solutions in relation to local administrative competencies regarding the Ministry that conducts consultations on civil data, Eliun, collect information and inform about land and other

3. Provide assistance for the construction of a basic structure and conflict resolution in accordance with the current engagement scale 
4. Seek solutions based on existing mechanisms to anticipate conflict or other forms of conflict that occur in the community.

5. Support for initiatives to assist, protect, and provide counselling to victims of domestic violence, service delivery and provide sanctions to reduce violations that occur within the community

6. Support the security forces to anticipate the following violations

7. Reports to the Village councils on the activities carried out or carried out each year for the community.

The aforementioned draft decree-law states that the role of the Village Chief is to coordinate the implementation of the decisions, which should be regulated by the Decree-Law itself, in order to ensure Village activities in the community. Local government powers such as:

1. Do not ask what to do;

2. Local government leaders Take decision to be based on community;

3. Ask the Aldeia, Select their Community Leaders (FetoMane), Desk and decide what they can do;

4. The Government only supports: material (Simenti, iron), Technical Support, Financial Support, Administrative Support;

The aforementioned Bridges have decided to achieve the results from the PNDS Projects: Roads, Bridges, Community Health Centre and Irrigation because the community's capacity is still unique and the same.

Local Government : Based on the regulation 3/2009, of July 8th, 2009, set out in the area of community leaders and their Election : "The Government recognizes that" Villages are a Community Organization that is shaped by common, cultural and traditional history, which relates to the historical and social relations that exist within the territory and within the defined population "and " the Government also recognizes that: aldeia is composed of population groups gathered in accordance with traditional relationships that are connected to the Villages due to historical and geographical ties "as well as the Village Chief, Village Council of Village, male and female youth representatives. 3/2009, of July 8th, 2009, with Village Autonomy (Village) as follows:

1. Peace and Social harmonization

2. Population Registration and Registration

3. Civic Education

4. Promotion of official languages

5. Economic Development

6. Food Security

7. Environmental Protection

8. Education, Culture and Sport

9. Help maintain social infrastructure such as Housing at Health Post, water sources, roads and communications.

More than the above points have already been written down to conclude that according to Law No. 3/2009, of July 8, 2009, it will empower the local government to carry out this role in accordance with the law. 3/2009, of July 8th, 2009:

1. The role of the Village Chief

a. Village Chief Representative;

b. Directing Village council meetings;

c. Coordinate the implementation of decisions taken by the Village councils;

d. In coordination with members of the Village council, promote consultation and discussion with the community to plan and implement the Village development program;

e. Selvorcing how to resolve small conflicts involving two or more villages; f. Promote the creation of mechanisms to promote domestic violence/home;

g. Support initiatives aimed at assisting victims of domestic violence and punish violence with the use of violence, with a view to supporting such behaviour in the community;

h. Coordinate with the security forces and ask their intervention in cases of conflict that are not resolved at the village level, if they are often present and disturbances;

i. Submit for the approval of the Village council's annual financial reports and activities carried out;

j. Cooperate with the municipal administration and Government representatives on procedures to be adopted in the development of Village activities.

With the above thinking, the group only wishes to formulate three (3) implications, namely:

1. Leadership relating to others (members or individuals). Members are determinant of a leader's successor. Members help and assist a leader's status or position in the process of leadership. The quality of leaders is irrelevant;

2. Leadership that has been reported about sharing the roles or powers between leaders and members. Leaders have competence and role in guiding all activities for their members. But members should not guide their leaders in any way;

3. The leaders that influence their members. The leader is not only leading or commanders members to work, but the leaders can influence members on how to work;

Therefore, the leadership is the capacity that someone has to influence others to work to achieve the objectives and goals.

According to teaching staff $(1995 ; 297)$ it is thought that: The effective leadership character is a superhero (supervisory) to direct and control, the provision of wood efforts in performance, creative thinking, has the ability to make fair and prudent decisions, Self confidence and self-reliance.

The aforementioned Bridges have decided that the leadership guide for the role of Task oriented leaders is to guide the members as they wish and focus on working with leaders who guide members of the community.

Local Development: Village development, as stated in the theory of the March theory (1984), is namely: Community Development based on a long term national economic foundations, with the aim of Village government authority, with local government administration authority supporting the acceleration of economic growth through a self-employed Village. Thus, this change in the position of Village development objects from all parties to strengthen national security.

Deferent from above the development goals on the basis of the community in the Village is a self-reliance to participate in development implementation. On the other hand, drafting programs to develop Villages and streamline equitable development.

Acording by Todaro (1982) believes that Village development in society has three targets, which are needed as follows:

1. Increasing the supply and expansion of the distribution or distribution of basic goods needed to survive, such as food, health growth, and protection;

2. Lifting the standard of living including increasing and increasing income, providing adequate employment opportunities, better education and human cultural values, all of this is not only to fulfill individual and national dignity;

3. Extending the range of economic and social options for all individuals and nationals by freeing them from slave attitudes and dependence not only in relation to others but from sources of suffering; 
From the above perspective, the development objective is mainly based on economic and social aspects, while the scope of the development of Village, economic, socio-cultural aspects and dependence on security. In theory above, the reader understands that the definition refers to the Government Program based on the National Strategic Development Plan (2011-2030) is the following basis:

1. Law No. 3 / 2009, 8 July (traditional leaders);

2. Decree-Law No..36 / 2015, 30 June, amending Decree-Law No. 4/2012, (Integrated Administrative Development Planning);

3. Government Resolution No. 1/2012, 15 January (Expediting Community Development);

4. Ministerial Diploma No. 22 / 2012, 27 June (Inter-Ministerial mission and Inter-Ministerial Technical Working Group);

5. Decree-Law No. 30 / 2015, 26 August, 1 - Amendment to Decree-Law No 08 / 2013, April 2013;

Based on the aforementioned points, it is noted that the Law, DecreeLaw, Ministerial Diploma and Government Resolution, sets out the fundamental rules to be implemented in accordance with the applicable law, in order to strengthen the development process in Timor-Leste, especially in the implementation of the Uatolari administrative post.

From the bases mentioned above, the National Program for Village Development (PNDS) is an initiative of the Government of TimorLeste that gives capacity to the community to choose to design small scale projects in their Villages. The PNDS is led by the Ministry of State Administration ( MAE) and the Ministry of Finance (MoF) in partnership with other ministries. Villages receive an annual grant of US $\$ 40.000$ - US $\$ 70.000$ directly from the Government to plan, build and manage their own country's small scale along the Village development activities. A infrastructure that can build or renew the water system, local roads, community centres or schools. The PNDS can participate in and manage its own development. Community Leaders are central to the program, PNDS seeks to create employment opportunities in rural areas and build community members' skills in building, procurement and accountability. Communities are supported by trained facilitators in financial, engineering and construction areas, and social inclusion. The Government of Timor-Leste expects to spend \$294.3 million on PNDS over the last 8 years from 2012 2020, as a Community Development Program provides an opportunity for communities to make positive and sustainable differences in their daily lives and living conditions through building experience frameworks from other countries - in the region specifically Indonesia shows that priorities from the community / PNDS are the following:

1. The PNDS program contributes to reducing poverty in rural areas by providing mechanisms for the national government to conduct direct and easy communication to the government to serve rural development needs;

2. Focusing on rural communities, women and vulnerable groups as they participate in planning, decision-making, implementation and monitoring of their priorities;

3. Strengthen and strengthen coordination lines and communication between the government and development partners at the national and sub-national level in order to develop an integrated and comprehensive National Development Program;

Through the above points it is written that PNDS is a community development program that provides opportunities for village communities to manage small scale development in accordance with the Village peri-urban area and thus has sustainability of people's daily lives through basic structures as required by the demands of living conditions of the people in rural areas.

Conceptual Framework: The role of the government in the implementation of local development is a direct action carried out between the local government and communities in order to achieve a good goal, as one of the key objectives in national reconstruction, with an open and effective nature in Timorese society. With these problems and addressing the current social situation - the economy of the people of Timor-Leste. The role of the government in development is to ensure sustainable development for the nation and the people of Timor-Leste.

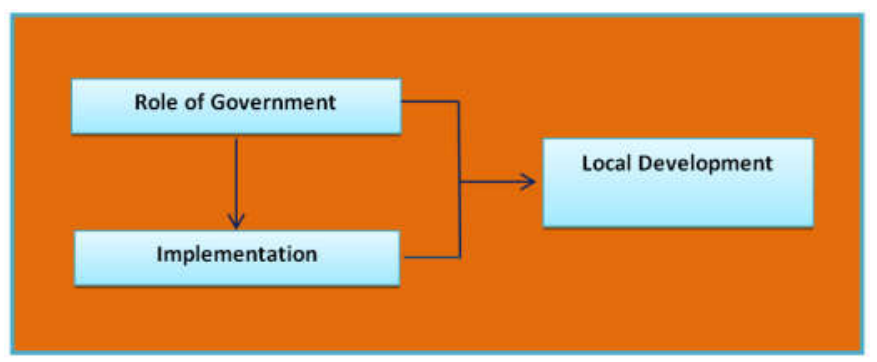

According to Riyadi (2002), the idea of a role is to guide the concept that is part of a social opponent in the community read.

Jones (1996) thought that in a decision setting out or in the implementation of activities, three main pillars of operation are to be carried out:

1. Organization; organizational activities are part of an effort and guidance towards achieving the objectives and targets of decisions;

2. Analysis; as a sequential interpretation or explanation activity of operational decisions and easy understanding, substantive decision-making undertaken and received by the author or project details;

3. Increasing; accurate application activities, payment or others based on the objectives of the decision;

The role of the Government is to follow up on the performance of the sub-district government aligned by community through a generation of elections. "The role of government in development according to Prajudi (2000). The government's duties are:" Among other things, state administration, State households, governance, development and environmental preservation. Meanwhile, the government functions are regulating, fostering community police and judiciary; "Amongst state administration, family or government, development and environmental prevention. It is considered the function of the government to regulate, promote potential and judicial community.

The aforementioned thinking is that when the local development role of the local government depends on the formulation of local government policy decisions in the Uatolari Administrative Post.

Based on the knowledge of the Government's role in implementing local development, as explained above, its assumptions about local development are:

1. The central government and local government played a vital role in overseeing, monitoring and decision making in the decision-making process that ended the role of the National Development Strategic Development Plan 2011-2030;

2. Implementation is the assumptions that are part of the diaspora Interaction lines that need to be addressed by the central government and local government as a process of learning about microgovernance of political dynamics, how to organize political systems and interact on the motivation of all parties in the implementation of decisions in a manner that respond to the needs of communities in the administrative post

3. Local development is one of the best PSCs in the world based on clear characteristics, such as before concluding the social problems to be attended and initiating intervention, the more serious thinking about how this problem has occurred and what is the best solution to the daily lives of communities, which are integral to society in remote or rural areas; 


\section{RESEARCH METHODOLOGY}

In this research method, farmers were used as qualitative research methods. According to Tohirin knowledge (2013:2), the qualitative research method is a research used to develop the owner and research participants' views through the words of the interview process with holistics (symenyeuh dan recommended). According to the aforementioned knowledge, Afifuddin (2009:57), the qualitative research method is a method used to research the nature of the research, write the owner as a tool, techniques for data collection, data analysis and qualitative research results, and the general scope of the qualitative research. On the basis of the above expertise, the owner said that the research method was used by the owner in order to conduct research in order to collect data, develop data, and then to obtain the results of the survey. In order to benefit from this Title "The Role of the Government in the Implementation of Local Development (Case Study on the National Village Development Program in Uatolari Administrative Post)"

\section{Approach and Type of Research}

Approach: Technical approaches such as ideas or ideas are derived from writing owners to approach researchers in conducting research based on research title. According to Syuddin (2005:68), technical approach is a way that is used to achieve instructional objectives. On the other hand, Nurses $(2009: 1)$ said that an approach that focuses on strategies and plans to achieve the objectives. According to the definitions above, the techniques described in this research are based on an approach that describes the role of the government and how to implement the development of the administrative post of uation.

Type of Research: The types of research outlined are qualitative types of research. As is known as Setyosari (2012:39) said, "justice for discrimination on crocodiles," (qualitative approach designed for the purpose or design of the syllabus, as well as expertise, expertise, an object under dispute to yang the pengan elite. "(qualitative approach description of the purpose or conditions, the event, the subject of the person or something related to the research).

Suggested and Research Object: The survey only informed that the subject and purpose used by the operator is the administrative post administrator, the village development officer, the village chief, and the community in Uatolari Administrative Post.

Research suggest: Subject to the population means that: generally (all or fully) are included in the survey, all the subject and subjective characteristics and quality, determined by Pesticiders, to carry out studies and findings for the survey.(Sugiyono, 2012;119) of this research defines all entities included in the administrative post administrator, Village development official, Village heads and community members in Uatolari Administrative Post.

Sample of Research: The purpose or sample of this research is to be the resources of the survey location where information is obtained, The researchers took the following objects: Infromante 1 as Postu Administrator, Chief 1 Village Development Officer 2, Community 2. Together, informants in this research are 6 individuals. According to the mentioned mentioned above, the Administrator of the Administrative Post as Local Government is responsible for development in the Villages, who are responsible for implementing and monitoring the development of the villages that are in the country's legal area, the Village Chief, a community leader who is responsible for local development in the villages under the leadership of the Village, the Village Development Agency, as implementing and monitoring of developments in the central areas of Village development, and the community in general.

Date Collection: The collection techniques or data collection are the main and most important step in this research because the purpose of the survey is to obtain the data according to the defined standard. Therefore, Sugiyono (2009:224) said that technicians collected data as a strategic tool that was carried out in a study because the main objective of this research was to obtain data. Sugiyono (2009:225) also stated that there is a qualitative method survey of data collection based on nature (conditions), first data source, and data collection techniques such as Technical observations, interviews and technical documentation.

Data Analysis: Data analysis was carried out prior to data collection in this research, during the survey and after research. Before providing a detailed explanation of the types of data analysis, data analysis was carried out in a single Sugiyono (2014:224) said that the data analysis meant that the trial results were conducted in a systematic and structured manner and that it could allow the writing of one of the researchers and others to better understand. In this research, as one of the writers (Pesticides) of this thesis intends to use techniques to analyse data based on the data obtained and then to develop and finally draw conclusions. Based on the aforementioned definitions, the owner wrote to conclude that, after collecting data from the research in a systematic manner or method, as written by the owner (researcher), using qualitative methods to analyse these data, and not using quantitative methods. Diagram qualitative research methods for verification and completion of data according to Matheus B knowledge. Miles and A. Michael Hubermen (1992 : 15).

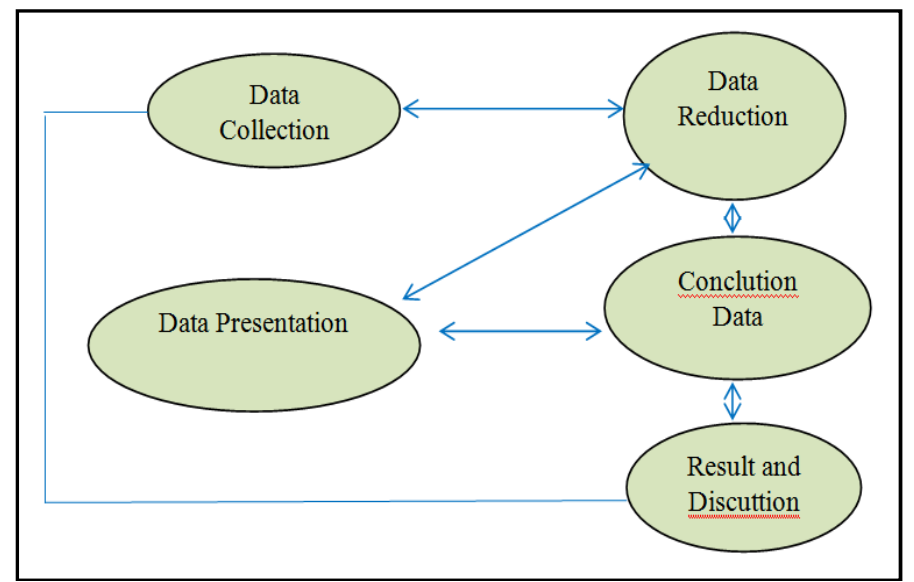

\section{RESULT AND DISCUSSTION}

Overview of the Research Area: In relation to this chapter, the owner described the results of the research carried out over a few weeks of study and discussed (Analysis) of the results, in order to find solutions for the identification and acquisition of problems based on the geographical conditions and demographic conditions of the Uatolari Administrative Post in relation to the research titled "The role of the Government in the implementation of Local Development. (Case Study of the National Program for Village Development in Uatolari Administrative Post) 2019-2020. ”

\section{Brief history of Uatolari Administrative Post}

Uatolari, due to the history of Timor Leste, is an administrative post that is the centre of six (6) Villages, at the administrative post of uation, in the Municipality of Viqueque. Administrative Posts in Uatolari Administrative Post, the person who runs over in the administrative post is called the Chief of Post. But between April 4, 2001 and July 2002 the sub-district chief and the name of the VicePrime Minister was changed to the Uatolari sub-district Administrator. From 2002 to 2003, it was moved to the Local Government. From 2003-2012, however in 2012 until now he has used the sub-district administrator, the Chief administrator of the administrative post of the posto. Tomas Soares da Silva.

\section{Description of Response or Informant}

The total number of people in this population is 6 people of all essential bridges at the administrative post of the Border Post. In this section, on the basis of sex, there are actions that exist in the administrative officer of Uatolari Sub-District. 
Monography of Uatolari Administrative Post

\begin{tabular}{llcccc}
\hline Name of Local & $\begin{array}{l}\text { Total } \\
\text { Aldeia }\end{array}$ & Total Family & Male & Female & Total \\
\hline Afaloikai & 10 & 1280 & 2701 & 2643 & 5344 \\
Babulo & 8 & 873 & 1564 & 1493 & 3057 \\
Macadique & 21 & 1699 & 3568 & 3752 & 7320 \\
Matahoi & 12 & 1401 & 2790 & 2955 & 5745 \\
Uaitame & 5 & 476 & 1117 & 1045 & 2162 \\
Vessoru & 7 & 476 & 1118 & 1044 & 2162 \\
Total & 63 & 6205 & 12858 & 12932 & 25790 \\
\hline Source : Uatolari Administrative Post
\end{tabular}

The Results Research: In relation to the research results, the survey was written and the use of interview methods directly with the respondent during the question and answer session, the researchers asked the Administrator of the Administrative Post to the community in Uatolari Administrative Post. The researchers then explained the respondents' identities in accordance with the knowledge of the respondent about the problem that occurred and identified information from the respondent to analyse qualitative data and tools used by the researchers in conducting interviews with the government's role in the implementation of local development that took place in the systematic Administrative Post. In this interview, conducted by researchers the Administrator of the Administrative Post, Official Development of Villages, Village Chiefs and the Community of uation Administrative Posts. Based on the aforementioned names, it is a source of research to understand the useful situation that occurred in the aforementioned Administrative Post and the names mentioned above were also the research sample and in the research used qualitative or inductive research methods which did not mean quantitative research but qualitative research.

Role of Local Government in the implementation of Village Development: According to the Administrator of the Uatolari Administrative Post, Mr. Tomas Soares da Silva expressed his concern about the role of the Local Government in the implementation of Village Development as the administrator of the Municipality Administrator, as the Administrator's Representative, gave support to the Government activities at the Administrative Post level, which aim to implement the development in six (6) Villages, in the Uatolari Administrative Post, through the Community Development Officer (CDO), to support and facilitate the development of programs at the administrative post level with the relevant sectors. Taking into account the above thought, the writer concluded that the role of the Local Government is the representative of the Administrator of the Municipality, who oversees the activities of the Government in the administrative post, in relation to the development program implemented in the administrative post. In accordance with the theoretical theory of the Law (1987) on "matters of governance that are specific in the ministry, will attend or treat with government functions with a sense of state, control and vital governance services with special tasks but with special attention to common interests with special characteristics. export needs to be provided in accordance with special services, directed by the competent ministries in the Central and regional or agency, according to local needs. According to the theory mentioned above, the central government has a specific power to regulate or fully control the implementation of development activities carried out in the country's productive sectors, with efficiency and effectiveness.

Program for the National Program for Village Development (PNDS) in Uatolari Administrative Post: According to the Administrator of the Salele Administrative Post, only six (6) of the PNDS program are going, because the PNDS program is a program that gives to each Village, depending on the criteria provided to the NPDS, the support provided to each Village will be carried out by the members of the NPDS, namely in the area of the Administrative Post of Baguia, Administrative Post of Viqueque (Village); the Administrative Post of Manatuto; the Administrative Post of Baguia, the Administrative Post of Viqueque (Village). Based on the aforementioned points, it is written to conclude that the above programs are a priority because they are the first time the people can facilitate rural communities, and therefore the administrative post administrator has the competency to support community initiatives, taking into account the priority areas for implementation of PNDS in the Villages planning, in relation to the services provided by each community in the Village, because the community serves the NPDS in accordance with these criteria. As such, the above opinion is based on the dignity of the Todaro (1982) theory, according to the Village development in the community, in the same way: 1 Increase the accessories and expansion of basic distribution materials according to the needs of nutrition, health growth and protection; 2 . Increase living standards that include the addition of adequate networks and provision of employment, the improvement of education in accordance with human values and the appropriateness of individual or national estimate; 3. Expand the economic and social options for individual or national individuals, freeing the dependence of the relationship of suffering bridges".

Relationship works according to the role of the Local Government and the Central Government in the implementation of the National Program for Village Development in Uatolari Administrative Post: The relationship between the Sub-District Administrator and the Central Government in terms of the implementation of the National Program for Village Development is how to channel information, identify and implement communication methods with the Vertikal as well as the horizon of the work of the local Government and the Central Government to the communities to ensure a role of responsibility in accordance with the local administration through the coordination of services in the implementation of large scale development:

Irigation : In 2019-2020, through the Central Government, it is implemented the Irrigation construction project in the Village of vessoru which is currently ongoing, I can say that I have achieved 30 $\%$, according to the Central Government's targets, the Project concluded on 15 March 2021, but we know that we have two years to follow our agreement between the Central Government and the Ministry of State Building for 2020, because it did not approve it in the dissemination of the Financial Year that the Irish Development Project will follow the time ahead.

Roads: In 2019-2020, the central Government implemented the project for the rehabilitation of the Lugasa Road Link Road to Village Afaloi-Naedala, Rehabilitation of the Uatolari public road to the administrative post of Uatocarabau, according to our geographical area, as the rehabilitation project of this road is $44 \mathrm{~km}$ and thus will have rehabilitation and rehabilitation of Mutin. At the same time, the ILO is pleased with the rural roads connecting between Quilikai Administrative Post and the uation Administrative Post of Iralere, Uasufa and Buibela.

Schools: In 2019 the administrative post of Uatolari, two school buildings will be inaugurated, namely the Escola Tecniku de Kalohedaeda and the Uatolari General School of Uatolari, in the short term, will be inaugurated. Through the PNDS program, it is up to the animals of the Pre-School children in the Village of vesweaving.

Community Health Centre: In the immediate administrative post of 2019 - 2020, the Community Health Centre in this Village has all been rehabilitated by the Ministry of Health and is highlighted with the employers in the community health centres.

Elektricity: In the Administrative Post of 2019-2020, the community residing in six Villages (6) and more than 20 thousand people have access to electricity, which in the remote area still doesn't have access to the Power Lina Electricity even though there are Airports with Fiemu directly connected to these areas but has not yet been moved to the Power panel because of the issue of the Budget, it is expected that in 2020 the government, through the companies that won the tender can be channeled to the power of the community in the areas: Loemma, Edem, Buumu, Bubule, Iraasuko, Buialaa, Nebela, and Nebel, and Nebel. 
Clean Water Program: In the immediate administrative post in 2019-2020, the PNDS will make available its contribution to communities in six Villages: Makadiki Village, Matahoi Village, Waitame Village, Babulu Village, Vessoru Village and Afalokai Village. Based on the above idea, the writer concluded that the working relationship between the Local Government and the Central Government, identifies and channel training and coordinates with the Community Development Officers (CDO) on the national and local development program at the Village level and administrative post level according to the role of the local Government in the implementation of the PNDS program and the national development program. The writer then writes Hdiyono dan Donny (1984) about "local government as a state equipment that always holds the interests of the regional community in the Village'.

(Source: Interview with Uatolari Administrative Post Administrator, 13-10 2020)

\section{Strategies and Motivation of Village Chiefs on ensuring development within the Village}

According to the Village Chief of Vessoru, Mr. Chiquito Lopes, Sim in Village vessoru a strategy for the development of the Village, but there is a lack of motivation from the community to ensure the development of the Village because the community itself does not have the same will, and therefore, the strategies that the Village is in the following situations:

a. Construction of Dardau irrigation, many communities did not want to be involved in the project, even though the project was beneficial to the village community itself;

b. The project is also based on the PNDS program to make sure water also exists for the community in the Village, but the community itself does not have the motivation to bring piped water, often water damage within the aldeia.

c. The play places for children Pre-school are welcome by the PNDS but instead of being careful and do not take advantage of the places to bring their children to learn here.

Based on the above points, it is written that the strategy and Motivation of Village Chiefs is concluded to ensure that development within the Village depends on the good will of the community, because the development within the Village is the beneficiary of the community and therefore ensures the development of the Village as owners of the development. Therefore, the writer took Bases for the role of the Village Chief as regulated by Decree Law Number : 5/2004 Articles 3 and 2.

Collaboration of Village and community leaders in Village Development: According to the Village Chief, the Village Chief, of the Village Chief, and the community in the Village Development, it is clear that there is no one or two communities who don't have the means to obtain it at the moment, but the Village Development should go forward, because the Government program is a program that does not share the information with us as a lesson for the strengthening of our decision to accelerate the implementation of the Village development, so that they cooperate with the Village development target that is intended to be developed by PNDS. Based on the above mentioned above, the writer concluded that the village chief should carry out his role in cooperating with the municipal administration and government representatives about procedures to be adopted in the development of activities in the Village, therefore, as a local government or community leaders, it is a determining factor for the development itself and the community feel that they have a sense of ownership of this development. Therefore, the aforementioned views are set out in the Law No. 3/2009, of July 8, 2009, regarding the village administrative services in the community or village.

Relationship works according to the role of the Local Government and the Central Government in the implementation of the National Program for Village Development in Uatolari Administrative Post
According to the Head of Village Vessory Village, we always have good coordination at the Village level, aldeia and administrative post level, how to coordinate the implementation of the PNDS program by the central government in the Village, especially through the training of the PNDS focal point, since the training of the PNDS focal point is aimed at ensuring that the PNDS funds are used according to the plan for the benefit of the actual beneficiaries:

a. Citizens participate and be involved in their local development;

b. Accelerate the development of infrastructures and access to public services;

c. Provide social and economic benefits to the community;

d. Sustainable and fair for all

Based on the aforementioned points, it is written that the relationship between the roles of the Local Government and the Central Government in the implementation of the National Village Development Program should have good coordination with the national, Municipality, administrative post to the Village because citizens participation and involvement in their local development is important in relation to the skills of communication necessary for the participation and community engagement. Therefore, written in accordance with the Teoria Edwin $(1995 ; 297)$ it is thought that: The effective leadership character is a supervisory leader (supervisory ability) to direct and control, The provision of wood efforts in the performance of the functions, creative thinking, has the ability to make fair and prudent decisions, Self confidence and initiatives themselves seek innovation according to the PNDS Program.

(Sources : Interview with Village Chief Vesoru, Mr. Chiquito Lopes ( 12-10-2020))

Strategies and Motivation of Village Chiefs on ensuring development within the Village

According to Community Leaders in Matahoi Village, Mr. Antonio Amaral believes that the strategy and Motivation of the Village Chief is namely:

a. accelerating infrastructure development and finding means by communities access to public services;

b. sustainable development is fair for all;

c. citizens participate and engage in their local development;

These three phases are that I am the Village Chief and encourage my community members in the village to ensure the development of those in the village, because the community is the owners or beneficiaries of the PNDS program. Based on the above points, it is written that the strategy and Motivation of Village Chiefs has been concluded to ensure development within the Village are citizens' participation and their involvement in development with this objective to ensure that development sustainability is fair to all communities, especially in developing basic infrastructure within the Village. According to the March 1984: Rural development is guided by a long term economic foundations for national development, with the aim of Village government authority with local government units in acceleration of economic growth in the villages of self-reliance to ensure the development of the Village.

Collaboration of Village and community leaders in Village Development: According to the Village Chief, I am concerned about the relationship between the Village Chief and the community in the village, because the community really belongs to the community as an important pillar in this development, because I as the Village Chief during the three (3) period I have been very well accompanied and I am aware of the progress of the community in relation to the development process, even though this is a major pillar in the period from 2019 to 2020 , I am not very effective because I have informed the community of monitoring our situation regarding the Government's budget regarding the current state budget, we have learned some problems that the State budget has been enacted during 
that the State budget process. Based on the aforementioned thinking, it is written that the community's monitoring of the national and local development process needs to have this information adequate to them in the Village, because the community is the key determinant of the development itself. Therefore the theory that goes on to refeous is the Ndraha theory (1992) on Village governance that is the lowest organisation below the decentralization that is placed below and directly responsible before the sub-district government in the quest. The Government is an individual group of legal authority that protects the conduct of decisions and decisions made by the government in accordance with the law and regulations that promote the full life of the community

Relationship works according to the role of the Local Government and the Central Government in the implementation of the National Program for Village Development in Uatolari Administrative Post

The relationship between the Head of Village or the Local Authority is intended to have the obligation under the law to operate with the municipal administration and the Government representatives on procedures to be adopted in the development of activities of the Village, indicating that the role of the Village Chief is to have a good relationship with the Administrator of the Administrative Post, CDO, OGL, Village Chiefs and the community to work together with the Central Government on the implementation of the PNDS in the Administrative Post, according to the criteria. Taking into account the above thought, the writer concluded that Working relations with the role of the village chief are good relations with the Administrator of the Administrative Post, CDO, OGL, other Village Chiefs and the community to work closely with the Central Government on how to manage the implementation of the development in the Villages, because the Village chief or local authorities are obliged by the law to adapt to the development of their activities within the Village. Bases of Decree Law No. 9/2018: Administrative Pre-ference Structures at the Administrative Post.

(Source: Interview with Matahoi Village Chief, Mr. Antonio Amaral (13-10 2020)

\section{Strategies and Motivation of Village Chiefs on ensuring development within the Village}

According to a Community Development Officer, Mr. Julio Sacadura believes in the uation Administrative Post, in relation to the strategy and Motivation of Village Chiefs on ensuring development within the Village:

a. Support to the Administrator of the administrative post and Heads to carry out their duties as a basis for development materials in the Village;

b. Take essential data on community development plans;

The two branches served as a Strategy and Motivation for Village Leaders on securing Development in the Village. The aforementioned thinking is that the Community Development Officer has decided to provide support to the administrative post administrator in the exercise of their functions; contact with development materials in the Villages, but there needs to be relevant data according to the needs of the community in the area of Village development. Bases of Decree Law No. 9/2018: Administrative Pre-ference Structures at the Administrative Post.

Workshop for Village and community leaders in Village Development: According to Mr. Julio Sacadura, a Community Development Officer at the uation Administrative Post, she believes that the relationship between the Village Chief and the community chief is a key tool for the successful development of the Village, because the community is the owner of the development itself, and the Community Development Officer only supports them based on the needs of the community based on this development objective.
In relation to the above thinking, the owner concluded that the maximum participation of the community in the implementation of the PNDS Project is to provide social and economic benefits to the Nation through the Movement for the benefit of a new community. Based on Government Resolution No.1/2015/2012,15 January on the acceleration of Community Development.

Relationship works according to the role of the Local Government and the Central Government in the implementation of the National Program for Village Development in Uatolari Administrative Post : According to Mr. Julio Sacadura Community Development Officer at the Administrative Post of uation, he considered working relations based on the role of the Local Government and the Central Government in the implementation of the National Village Development Program (PNDS), CDO has been conducting coordination with the Administrator of the administrative post of the National Development Program at Village and Administrative Post level and how its implementation is done at Village level and Administrative Post level.

In relation to the above mentioned above, the writer concluded that the role of the Local Government and the Central Government in the implementation of the National Village Development Program (PNDS) is the role of the central government: comprehensive (objective, project, budget / fund), general guidelines, Financial Support, Monitoring, evaluation and evaluation of community level development, government support administration. The Director writes the Joint Ministerial Diploma No. 22 / 2012, 27 June (InterMinisterial mission and Inter-Ministerial Technical Working Group);

\section{(Source : Interview with Community Development Officer, Mr. Julio Sacadura,13-10 2020)}

Effectiveness and effectiveness of the National Program for Village Development (PNDS) in the Administrative Post of Uatolari: As Andre Lopes, the Vessor Village community views on the effectiveness of the implementation of the Village Development Program in Vessoru Village, despite the fact that the implementation of the PNDS program has not been effectively implemented, because the program has not yet had a good coordination of the PNDS managers in the Villages, in relation to the community's priorities, it is actually a program that the NPDS is a program that has been implemented by the community itself. In the Village Vessory Program, only two of the PNDS programs are the first time that there is no monitoring of Preschool children in their home, the second is Water Supply and also for the communities in Vessoru Village, but often the distribution of water is not suitable due to lack of effective monitoring of water for the community and the maintenance of the water supply, if there is a time for the population or pumps. During the period 2019-2020 in Vessory Village, the Daradau Construction Project has been ongoing since March 2019 and is now being developed by the local government and the central government and the central government have not yet received the attention of the project as soon as possible, so the Central Government has to move down quickly, as the project has been satisfied with the number of years since Indonesian times until there has been a lot of control over the irrigation because they have been heavy rainfall due to a heavy rains in the community. Of the above thinking, the owner wrote one to conclude that mentality needs to be changed, as: What can we do? Dont wait until the government comes! We can plan, Manage, and develop our own community! These three phases can be overcome means that we are starting to change community mentalities, which always depend on the Local Government or the Central Government, do not want to take part in these processes but also on the other hand, which are the owners and beneficiaries of the development within the Village.

Based on Jones thought (1996), in the decision making process, or in the implementation of activities to be carried out according to a program based on three important measures of implementation: 
1. Organise; organizational activities are part of an export to achieve objectives and targets for decisions;

2. Interpretation; as research activities for interpretation or substantially explanation of operational decisions and easy understanding, the substance of the decision undertaken and received by the author or the timeline of decisions;

3. Inconsistent application activities, payment or others are provided for the purposes of the decision targets;

\section{Village Chief and community collaborations in Village Development?}

According to Mr. Andre Lopes, as explained by the Vessory Village community, during that time he spoke with the Village Chief and community members in the village, because many times the development that is in the Village Chiefs does not really have a good relationship with the informal community, such as the construction of Irish Aid, Dardau Village Chiefs, used others to construct the project even though many youth are not working in or not part of this construction work to obtain some money to meet their needs every day. Development in the village has been working well and there has not yet been a discussion of community leaders and their community. The aforementioned thought was written by the owner of the village, who wanted to conclude that the prayer of the Village Chief and the community in the village was important as to how to discuss and decide what they could do in the village, because through a spirit of collaboration between the community leaders and the community in the market. It was written on the basis of Government Resolution No.1/2015/2012,15 of January on the acceleration of Community Development.

(Source: Interview with Mr. Andre Lopes, Vessor Community ,14-10 2020)

Effectiveness and effectiveness of the National Program for Village Development (PNDS) in the Administrative Post of Uatolari

According to Almicar da Cruz, the Matahoi Village community views on the effectiveness of the Village Development program in Matahoi Village, during 2019-2020 Village, as well as the Village of Uatolari administrative post, from the Village's effectiveness and efficiency of the PNDS program, as well as on the criteria set out in the NPDS program, but its control is necessary to improve the quality of the operation so far as it can be done by the community, because it is already the program owner of the PNDS's program, which needs to be managed by the community as a result of the priority projects that need to be managed by the community.

The aforementioned thinking is that the following are written down: the demands of the community are:

1. They develop themselves;

2. The community is primarily leading the development;

3. Discuss and decide what they can make

These three branches are key factors for local development in the village. Therefore, the writer was written on Government Resolution No. 1 / 2012, 15 January on how Community Development Accelerate with Aid Effectiveness and Effectiveness in accordance with the goals of the PNDS program.

Collaboration of Village and community leaders in Village Development

According to Mr. Almicar da Cruz, the Matahoi Village and community leaders, Mr. Almicar da Cruz Community members, pointed out that the PNDS program has contributed to reducing poverty in rural areas, Provide mechanisms for the national government to provide direct and easy communication to the government to meet the needs of rural development, because the participation of village councils is directly linked to community leaders and community leaders as a determining factor in the development of Villages through the strengthening and strengthening of communication lines between government and development partners in order to develop integrated programs and national development. The PNDS program is being implemented in Matahoi Village, which will improve access and quality of public service delivery: Roads, Ahi, Water, Education, Health and Market.

The following views have been written down to conclude that community participation in the implementation of the project areas of intervention: Basic infrastructure, Community attitudes change, Productions, Poverty Reduction (Condition of Life and Consumption). From the above four points, the results of the PNDS program are key to strengthening coordination and communication between the Government and development partners at the national and sub-national level, in order to develop integrated and comprehensive national development programs in the Villages program. Write the owner of the Decree-Law No..36 / 2015, 30 June, 1 - amending Decree-Law No. 4/2012, on integrated development planning, in order to have a good prayer between community leaders and the community in development. (Sources: Interview with Mr. Almicar da Cruz, Matahoi Community, 14-10 2020)

\section{OVERVIEW OF THE RESEARCH RESULTS}

This results were presented based on interviews conducted by a team of six informants, comprising the Sub-District Administrator, one of the CDO administrative staff, two Village Chiefs, community representatives from the Vessoru village, and the Matahoi Village community, which took place in October 2020. The purpose of the presentation was to clarify the views of informants on the role of the Government in the implementation of Local Development (Case Study in the Uatolari Administrative Post), as follows:

The village chief strategy and Motivation of Village Chiefs is aimed at ensuring the development of this the strategy and Motivation that the Village Chief has in place to ensure development within the Village are:

a. accelerating infrastructure development and finding means by communities access to public services;

b. sustainable development is fair for all;

c. citizens participate and engage in their local development;

Researchers concluded that these three points are the ones that Village Chiefs do and encourage my community members in the Village to ensure that they are in the Villages, because the community is the owners or beneficiaries of the PNDS program themselves.

The role of the Local Government in the implementation of Village development: The role of the Local Government as Head of Municipality Administrator and Head of Government is related to Government activities at the Administrative Post level, researchers conclude that the Administrator of the Sub-district Administrators Gere and guide staff in the local power level of the Administrative Post level, Canaliza information as Community / Village needs for the Administrator of the Municipality of Relations between the Local Government and the Central Government, Identify and implement or implement training sessions in coordination with the Community Development Officers (CDO) on the national and local level of Village and administrative post of the local Government.

Collaboration of Village and community leaders in Village Development: In relation to the collaboration between the Village Chief and the community in the area of Village development, the Researchers concluded that there was a strong desire to work together with a good coordination between the administrators and community leaders in the administrative post, although there were problems that exist, notably through the means of Vertikal and Hortal communication, contributing to the implementation of the program by 
the central government as well as some activities of the community that were given better service delivery by all parties.

Priority programs in the National Program for Village Development (PNDS): The Priority Program in the National Program for Village Development (PNDS) is: Roads, Roads, Water, Education, Health and Market of the priority programs mentioned above, which points to the fact that the programs mentioned above are: Roads, Health and Market Development Program based on the demands made by the community: Communities plan, decide, manage funds, accountable for the results and funds spent, operating and maintenance of the funds.

Relationship works according to the role of the Local Government and the Central Government in the implementation of the national village development program in the

Relationship works according to the role of the Local Government and the Central Government in the implementation of the National Program for Village Development at the administrative post, To ensure that the PNDS program funded is used in accordance with the plan for the benefit of beneficiaries, the Researchers concluded that the Social facilitators of the Administrative Post and Municipality Coordinators will see that Villages control the process and comply with established rules and regulations, and technicians from the Municipality will assist with the design and supervision of the construction, certify progress and quality.

Effective efficiency and effectiveness of the National Program for Village Development (PNDS) in the Uatolari Administrative Post

Effective efficiency and effectiveness of the National Program for Village Development (PNDS) in the administrative post of Uatolari, researchers have found that the effectiveness of the National Program for Village Development is to ensure the quality of community service provision within the Village, in accordance with the service area and skills, so that they can operate responsibly and there is a better motivation to work towards the capacity building of the PNDS technical staff in the Villages.

The views described in this description are findings from the Impormants that the implementation of Local Development Program, according to the National Program for Village Development in the Administrative Post, has raised new things in the community:

1. PNDS Advisor has a positive impact on poor people's access and use of basic services, particularly in Health, Education, Rural Roads and Access to Drink Water;

2. Improve access and quality of public service delivery (roads, roads, water, education, health and market);

3. Communication skills necessary for community participation and engagement organised community;

4. Continued participation of communities in the implementation of the PNDS Project;

5. Technical skills for construction and maintenance, procurement and accounting skills (finance);

6. Poverty reduction (living conditions and consumption);

7. Quality of General Controls:

a. $94 \%$ of the project is the result of the evaluation of MEDIU (average) and Good.

b. $6 \%$ of the projects evaluated by the evaluation results need to be improved, based on the imposed improvements.

\section{ENDCLOSED}

\section{CONCLUTION}

Based on the results of the research, undertaken in preparation for the KAPITULU IV, the owner wrote the conclusions based on the results of the research on the role of the Government in the implementation of Local Development in Uatolari Administrative Post:

1. The implementation of the Development of the Administrative Post in the area of Infrastructure Development during 2019-2020, went well and followed by the expectations of the People on how to facilitate them in the economic development of the products and reduce poverty (living conditions and consumption) in the administrative post

2. The role of the Government in the implementation of the tile administrative post will be Minus of control, so it is necessary for the Central Government to monitor and control the progress of the construction activities to be achieved in a timely manner.

3. Administrative Post of Uatolari need to be technical and intensive. Since Vokal there are administrative posts like $\mathrm{CDO}$ as a guide for the implementation of the Development in the Administrative Post, the general situation will need to be assisted with effective techniques in the area,because guidelines are problems, Quality Skill, capacity and dedication as a focal point for raising their knowledge to help local governments.

Sugestion: As a result of the problems or conclusion, the researchers will suggest to the Local Government to provide proper information. Since the research team will provide the following suggestions:

1. Ministry of State and Territorial Planning needs to pay attention to the work of the ADN Municipal in Viqueque to speed up the implementation process of local development expectations, especially the development of a frastructuring environment which is currently in line with the National Strategic Development Plan

2. The Administrator of the post needs to carry out his duties under the responsibilities set out in the Decree Law No. 9/2018, on the Administrative Pre-mediate Structure of the State and Territorial Planning;

3. Further increase the Human Resources of $\mathrm{CDO}$ and Municipality Engineers will assist and review the design and supervision of Construction, Certification and Quality of implementation of the National Village Development Program;

4. Need the Financial Facilitators of the Administrative Post and Network of PNDS to carry out regular monitoring of the Villages to confirm that the management of the program is done according to the PNDS Guidelines

5. Communities need to provide a better solution to ensure and exercise control over the implementation of Development in the Administrative Post and to achieve the goals that are in line with their own development goals;

Theoritical Implication: The role of the Government in the implementation of Local Development in the administrative post of Uatolari, namely: Irrigation, Roads, Roads, Community Health Centre, Community Health Centers, Power and Water as well as during the Central Government, Local Government and communities implemented in the administrative post of Baguia according to the criteria required by PNDS and how to accelerate the development of infrastructure and find ways in which the community can access to sustainable public services, equitable development of all citizens, participate in the development of their local development goals according to the National Development Plan (PEDN). " Communities need to provide a better solution to ensure and exercise control over the implementation of Development in the Administrative Post and to achieve the goals that are in line with their own development goals;

Practical Implication: With the research results on the role of the Government in the implementation of Local Development, it is an suggestion that there is a better relationship between the Central Government, the Local Government and the Community, so that the communities can remain active in the activities of Village development and administrative post so that future development can 
only strengthen the capacity of each other, the capacity of local government to increase the delivery of local development results in the Villages whose communication is currently underreceived.

\section{REFERENCE}

Bambang , Juani, 1993, Administrasi Pembangunan Desa, APDN, Bandung;

Budiman, Arief, 2000, Teori Pembangunan Dunia Ketiga, Gramedia Pustaka utama, Jakarta;

Djodari , JRG, 1997, Kebijakan Pemerintahan, Yarsif Watampone, Jakarta;

Hadiyono \& Danardono, Doni, 1994, Prospek Pemerintah Daerah dengan Otonomi Luas, Universitas Sogijapranata, Semarang;

Husnul Imtihan (Neo-Bis Vol. 11,No 1,Juni 2017 ), Peran Pemerintah Dan Partisipasi Masyarakat Dalam Perencanaan Pembangunan Daerah (Musrenbang Ds. Taman Sari Kecamatan Gunung sari Kabupaten Lombok Barat 2016).

Kansi., 1987, Hukum Tata Negara Republik Indonesia, Rineka Cipta Jakarta;

Koontz \& Daniel, 1997, Evaluasi suatu Sistem Untuk Proyek Pembangunan, Bina Aksara, Jakarta;

Kuncoro, mudraja,2000, Ekonomi Pembangunan: Teori, Masalah dan Kebijakan, UPPAMP YKAPN,Jakarta;

Lukmanul Hakim (Jurnal Politikom indonesia,Vol.2.No.2,2017), Partisipasi masyarakat dalam pembangunan desa sukamerta kecamatan Rawamerta Kabupaten Karawang.

Marsono, Suharsono H., 1984, Metodologi Penelitian, LP3ES, Jakarta;

Moeleong, Lexy J., 2002, Metode Penelitian Kualitatif, Rosda Karya, Bandung;

Muchlas M. Tahir (Jurnal Ilmu Pemerintahan Vol. 8, No.1, Januari 2015 , Good Urban Governance: Peran Pemerintah dalam Pembangunan Wilayah Kecamatan di Kota Makassar.

Muchlas M. Tahir (Jurnal Penelitian Sosial dan Politik,Vol.6 no.4,2017), peranan kepala desa dalam pelaksanaan pembangunan di desa pekik nyaring kecamatan pondok kelapa kabupaten Bengkulu Tengah
Nawawi, Hadri, 2003, Metode Penelitian Bidang Sosial, Gadjah Mada University Press, Yogyakarta;

Ndraha, Talizihudu, 1992, Metodologi Pembangunan Desa, Bina Aksara, Jakarta;

Ryadi, Slamet, 2001, Masyarakat dalam Pembangunan, Bumi Aksara, Jakarta;

Sigarimbun, Masri \& Efyan, 1989, Metode Penelitian Survey, LP3ES,

Soejito, Irawan, 1990, Hubungan Pemerintah Pusat dan Pemerintah Daerah, Rineka Cipta Jakarta;

Syafiie, Inu Kencana, 2000, Ilmu Politik, Rineka Cipta, Jakarta;

Tedore, Michael P.,1982, Pembangunan Ekonomi, Ghalia Indonesia, Jakarta;

Tjokoamidjojo, Bintoro, 1998, Pembangunan: Dasar-Dasar Pengertiannya, Usaha Nasional, Surabaya;

Umar sune (Jurnal politik dan social kemasyarakatan,Vol.11,no.3, 2019), Kinerja kepala desa dalam pembangunan insfrastrutur desa sidorukun kecamatan Randangan Kabupaten Pohuwato.

Usman, Husaini, \& Akbar, Purnomo Setiady, 2000, Metode Penelitian sosial, Bumi Aksara, Jakarta;

\section{OTHER RESOURCE}

Asembleia Konstituente, 2002, Konstituisaun República Democratica de Timor-Leste

Decreto Lei No.5/2004, Papel Chefe Village, Ministerio Administrasaun Estatal e Ordenamentu Terotorio, Dili, 2004.

Lei Nú. 3/2009, 8 Jullu (Lideransa Tradisionál)

Dekretu-Lei Nú.36 /2015, 30 Junhu, 1. ${ }^{a}$ alterasaun ba Dekretu Lei Nú. 4/2012, (Planeamentu Dezenvolvimentu integradu Disitrál)

Rezolusaun Governu Nú. 1/2012, 15 Janeiru (Aselera Dezenvolvimentu Komunitária)

Diploma Ministeriál Konjuntu Nú. 22/2012, 27 Juñu (Kommisaun Inter-Ministeriál no Grupu Traballu Inter -Ministeriál)

Dekretu-Lei Nú. 30/2015, 26 Agostu, 1. ${ }^{\text {a }}$ alterasaun ba Dekretu Lei PNDS Nú. 08/2013, Abríl 2013 